\title{
The Impact of Climate Change on the Resistance of Rice Near-Isogenic Lines with Resistance Genes Against Brown Planthopper
}

\author{
Yun-Hung Kuang ${ }^{1}$, Yu-Fu Fang ${ }^{1}$, Shau-Ching Lin' ${ }^{1}$, Shin-Fu Tsai ${ }^{1}$, Zhi-Wei Yang ${ }^{2}$, Charng-Pei Li ${ }^{3}$, \\ Shou-Horng Huang ${ }^{4}$, Sherry Lou Hechanova ${ }^{5}$, Kshirod K. Jena ${ }^{5,6}$ and Wen-Po Chuang ${ }^{1 *}$ (D)
}

\begin{abstract}
Background: The impact of climate change on insect resistance genes is elusive. Hence, we investigated the responses of rice near-isogenic lines (NILs) that carry resistance genes against brown planthopper (BPH) under different environmental conditions.

Results: We tested these NILs under three environmental settings (the atmospheric temperature with corresponding carbon dioxide at the ambient, year 2050 and year 2100) based on the Intergovernmental Panel on Climate Change prediction. Comparing between different environments, two of nine NILs that carried a single BPHresistant gene maintained their resistance under the environmental changes, whereas two of three NILs showed gene pyramiding with two maintained $\mathrm{BPH}$ resistance genes despite the environmental changes. In addition, two NILs (NIL-BPH17 and NIL-BPH20) were examined in their antibiosis and antixenosis effects under these environmental changes. BPH showed different responses to these two NILs, where the inhibitory effect of NIL$\mathrm{BPH} 17$ on the $\mathrm{BPH}$ growth and development was unaffected, while NIL-BPH2O may have lost its resistance during the environmental changes.

Conclusion: Our results indicate that BPH resistance genes could be affected by climate change. NIL-BPH17 has a strong inhibitory effect on BPH feeding on phloem and would be unaffected by environmental changes, while NIL$\mathrm{BPH} 2 \mathrm{O}$ would lose its ability during the environmental changes.
\end{abstract}

Keywords: Nilaparvata lugens, Near-isogenic lines, Climate change, Insect resistance gene, Host plant resistance

\section{Background}

Rice (Oryza sativa L.) is an important staple cereal crop in Asian countries. It feeds more than half of the world's population (Jena and Kim 2020), in which global rice production is approximately 782 million tons (FAOSTAT 2020). However, rice pests, such as Nilaparvata lugens Stål, Nephotettix virescens Distant, Sogatella furcifera Horváth, Chilo suppressalis Walker, and

\footnotetext{
* Correspondence: wenpo@ntu.edu.tw

'Department of Agronomy, National Taiwan University, Taipei 10617, Taiwan Full list of author information is available at the end of the article
}

Cnaphalocrocis medinalis Guenée, have been causing a severe impact on rice production, resulting in a potential $13 \%$ to $26 \%$ yield loss (Oerke 2006). N. lugens (brown planthopper; $\mathrm{BPH}$ ) is the most destructive rice pest in Asia. $N$. lugens directly damages the crop by sucking the phloem sap and causes a plant mortality symptom called the "hooper burn." During feeding, N. lugens could transmit the grassy and ragged stunt viruses to the rice plant. Millions of dollars have been lost due to the N. lugens infestation in rice in Southeast Asia (Herdt 1991).

In addition, more than 1.8 trillion tons of carbon dioxide $\left(\mathrm{CO}_{2}\right)$ have been released into the atmosphere due to

\section{Springer Open}

(- The Author(s). 2021 Open Access This article is licensed under a Creative Commons Attribution 4.0 International License, which permits use, sharing, adaptation, distribution and reproduction in any medium or format, as long as you give appropriate credit to the original author(s) and the source, provide a link to the Creative Commons licence, and indicate if changes were made. The images or other third party material in this article are included in the article's Creative Commons licence, unless indicated otherwise in a credit line to the material. If material is not included in the article's Creative Commons licence and your intended use is not permitted by statutory regulation or exceeds the permitted use, you will need to obtain permission directly from the copyright holder. To view a copy of this licence, visit http://creativecommons.org/licenses/by/4.0/. 
human-related activity since the Industrial Revolution (Allen et al. 2009), with the greenhouse gas, $\mathrm{CO}_{2}$, increasing the atmospheric temperature of the earth. The Intergovernmental Panel on Climate Change (IPCC) predicted that the atmospheric temperature will increase by at least $1.5^{\circ} \mathrm{C}$ before 2030 and $2{ }^{\circ} \mathrm{C}$ before 2050 (Stocker et al. 2013). Furthermore, climate change would increase the frequency of extreme weather events, such as droughts, water shortages, floods, and typhoons. In addition to the environmental stresses, crop plants may have a higher frequency of insect herbivory damage. It is also predicted that global warming would increase the insect population size and metabolic rates, which could cause substantial crop yield losses (Deutsch et al. 2018). Thus, climate change is predicted to have a severe impact on the staple food production and food quality.

Planting insect-resistant crops is one of the main strategies for integrated pest management (IPM). In rice, more than $30 \mathrm{BPH}$-resistant genes have been identified (Du et al. 2020), where the BPH4 gene was identified in Babawee (Sidhu and Khush 1979), while the dominant gene, $B P H 9$, was identified in the rice cultivars Kaharmana, Balamawee, and Pokkali (Murata et al. 2001). The $B P H 10$ gene was found in an introgression line from $O$. autraliensis (Ishii et al. 1994), while BPH17 was identified from the Sri Lankan indica rice cultivar, Rathu Heenati (Sun et al. 2005). In addition, BPH18 was found in $O$. australiensis (Jena et al. 2006), while BPH2O and BPH21 were identified from O. minuta (Rahman et al. 2009). Moreover, $B P H 26$ was identified from the indica cultivar ADR52 (Myint et al. 2012), in which BPH32 (old name $B P H 3)$ was identified in the rice variety PTB33 (Jairin et al. 2006; Ren et al. 2016). In addition, $14 \mathrm{BPH}$ genes (BPH1, BPH2, BPH3, BPH6, BPH7, BPH9, BPH10, $B P H 14, B P H 15, B P H 18, B P H 21, B P H 26, B P H 29$, and $B P H 32$ ) have been cloned ( $\mathrm{Du}$ et al. 2009; Jena et al. 2017; Ji et al. 2016; Liu et al. 2015; Ren et al. 2016; Tamura et al. 2014; Wang et al. 2015; Zhao et al. 2016). Currently, many BPH-resistant genes have been used to develop insect-resistant varieties through markerassisted selection.

Although many BPH resistance genes have been identified, a BPH-resistant rice variety would probably be overcome by $N$. lugens within a few years after being released into the market, since $N$. lugens has multiple biotypes and is prone to gain resistance (Stout and Davis 2009). Based on the studies of the resistance responses of $N$. lugens biotypes, BPH-resistant varieties gradually lose their resistance (Cheng and Chang 1979; Huang et al. 2009; Smith 2005). Furthermore, temperature affects the virus or insect resistance in plants (Fahim et al. 2012; Wang et al. 2010). Several virus-resistant genes in wheat would lose their resistance under high temperatures $\left(18^{\circ} \mathrm{C}\right)$ (Fahim et al. 2012), where two insect resistant varieties (IR26 and IR36) that carried a single $\mathrm{BPH}$-resistant gene lost their resistance when the temperature increased up to $31{ }^{\circ} \mathrm{C}$ (Wang et al. 2010). To date, the number of $\mathrm{BPH}$-resistant genes that have been affected by environmental changes is unclear.

Furthermore, reducing pesticide usage without decreasing the sustainable crop production is a major challenge. Unfortunately, global pesticide sales increased dramatically from 2000 to 2012 in Asia (Lamichhane et al. 2016). Thus, planting the insect-resistant variety instead of spreading the pesticide is a better strategy to sustain the planet. However, in order to keep the insectresistant variety sustainable, the impact of climate change on these insect-resistant varieties needs to be considered. The success of using insect-resistant genes is based on the understanding of whether these genes would maintain their resistance traits under climate change. Otherwise, the misuse of insect-resistant genes will not only have no gain in crop production, but also potentially cause the loss of resistance. Hence, in this study, a series of rice near-isogenic lines (NILs) carrying BPH-resistant genes (BPH4, BPH9, BPH10, BPH17, BPH18, BPH20, BPH21, ВPH26, ВPH32, ВPH $2+32$, $B P H 18+32$, and $B P H 9+32$ ) (Jena et al. 2017) (Table 1) from the International Rice Research Institute (IRRI) were tested for their resistance responses under three environmental conditions (the atmospheric temperature with corresponding carbon dioxide at the ambient, year 2050 and the year 2100) based on the IPCC prediction (Stocker et al. 2013). The standard seed-box screening test (SSST) as well as examining the antibiotic and antixenosis effects of these NILs was performed to evaluate the resistance under environmental changes. The results of this study would provide information to rice breeders for future breeding programs to implement IPM strategies.

\section{Results \\ SSST under Climate Change}

A total of 12 NILs and IR24 (background cultivar) were evaluated in their ability to resist $N$. lugens under three environmental conditions (ambient, 2050, and 2100) using the SSST (Table 2). A two-way ANOVA was used to analyze the damages across the different environmental settings, where the damage score was found to be significantly affected by variety $(P<0.001)$ and environment $(P=0.006)$ (Table 3). Under the ambient setting, 11 NILs (NIL-BPH4, NIL-BPH9, NIL-BPH10, NIL-BPH17, NIL$B P H 18, \quad$ NIL-BPH20, NIL-NPH21, NIL-BPH26, NIL$B P H 2+32$, NIL-BPH18 + 32, and NIL-BPH9 + 32) had a lower damage score compared to IR24 (Table 2), while NIL-BPH32 had a high damage score, which was similar to that of IR24. Under the 2050 setting, five NILs (NILBPH17, NIL-BPH20, NIL-BPH2 + 32, NIL-BPH18 + 32, 
Table 1 The chromosome number and linked markers of BPH resistant genes in NILs

\begin{tabular}{|c|c|c|c|c|}
\hline NILs & $\begin{array}{l}\text { BPH resistance } \\
\text { gene }\end{array}$ & Chromosome & Linked markers & References \\
\hline $\mathrm{NIL}-\mathrm{BPH} 4$ & $\mathrm{BPH} 4$ & 6 & RM589, RM586, RM190 & (Jairin et al. 2010) \\
\hline $\mathrm{NIL}-\mathrm{BPH} 9$ & BPH9 & 12 & RM5341,RM463 RM28502, InD2 & (Su et al. 2006) \\
\hline NIL-BPH10 & BPH10 & 12 & RG457,RM277, RM260 & (Ishii et al. 1994) \\
\hline NIL-BPH17 & BPH17 & 4 & RM518,RM8213, RM5953,RM401 & (Sun et al. 2005) \\
\hline NIL-BPH18 & BPH18 & 12 & 7312.T4A, BPH18-ind2 & (Jena et al. 2006) \\
\hline NIL-BPH2O & $\mathrm{BPH} 2 \mathrm{O}$ & 4 & S4019 & (Rahman et al. 2009) \\
\hline $\mathrm{NIL}-\mathrm{BPH} 21$ & $\mathrm{BPH} 21$ & 12 & S12094 & (Rahman et al. 2009) \\
\hline $\mathrm{NIL}-\mathrm{BPH} 26$ & $\mathrm{BPH} 26$ & 12 & RM309, RM28449, S20103, RM5479, MSSR2 & (Yara et al. 2010) \\
\hline NIL-BPH32 & BPH32 & 6 & RM589, RM588, RM8072, PASH6 & (Ren et al. 2016) \\
\hline $\mathrm{NIL}-\mathrm{BPH} 2+32$ & $\mathrm{BPH} 2 / \mathrm{BPH} 32$ & $12 / 6$ & RM463, RM3331, RM589, RM588, RM8072, PASH6 & $\begin{array}{l}\text { (Murata et al. 1998; Ren et al. } \\
\text { 2016) }\end{array}$ \\
\hline NIL-BPH18 + 32 & BPH18/BPH32 & $12 / 6$ & $\begin{array}{l}\text { 7312.T4A, BPH18-ind2, RM463, RM3331, RM589, RM588, } \\
\text { RM8072, PASH6 }\end{array}$ & $\begin{array}{l}\text { (Jena et al. 2006; Ren et al. } \\
\text { 2016) }\end{array}$ \\
\hline $\mathrm{NIL}-\mathrm{BPH} 9+32$ & BPH9/BPH32 & $12 / 6$ & $\begin{array}{l}\text { RM5341, RM463, RM28502, InD2, RM589, RM588, RM8072, } \\
\text { PASH6 }\end{array}$ & $\begin{array}{l}\text { (Su et al. 2006; Zhao et al. } \\
\text { 2016) }\end{array}$ \\
\hline IR24 & - & & & \\
\hline
\end{tabular}

and NIL-BPH9+32) had a lower damage score compared to IR24 (Table 2), while seven NILs (NIL-BPH4, NIL-BPH9, NIL-BPH10, NIL-BPH18, NIL-BPH21, NIL$B P H 26$, and NIL-BPH32) had a high damage score, which was similar to that of IR24. However, under the 2100 setting, six NILs (NIL-BPH17, NIL-BPH20, NIL$B P H 26$, NIL-BPH32, NIL-BPH18 + 32, and NIL-BPH9+ 32 ) had a lower damage score compared to IR24 (Table 2), while six NILs (NIL-BPH4, NIL-BPH9, NIL-BPH10, NIL-BPH18, NIL-BPH21, and NIL-BPH2+32) had a high damage score, which was similar to that of IR24. Hence, these results indicate that some of the BPH resistance genes may have been affected by the environmental changes.

When comparing across the different environments, eight NILs had changed their resistance level under the environmental changes. Within these NILs, five of them
(NIL-BPH4, NIL-BPH9, NIL-BPH10, NIL-bph18, and NIL-BPH21) were resistant in the ambient setting, but they lost their resistance under the 2050 and 2100 settings. NIL-BPH26 was resistant in the ambient and 2100 settings, but lost its resistance by 2050 . In addition, the NIL- $B P H 2+32$ showed resistance under the ambient and 2050 settings, but lost its resistance under the 2100 setting. Furthermore, NIL-BPH32 showed no resistance under the ambient and 2050 settings, but it regained its resistance under the 2100 setting. Moreover, four NILs (NIL-BPH17, NIL-BPH20, NIL-BPH18 + 32, and NIL$B P H 9+32)$ were unaffected by $N$. lugens, and hence, were resistant to the environmental changes. Overall, two of the nine NILs that carry a single BPH resistance gene maintained their resistance to the environmental changes, whereas two of the three NIL gene pyramids

Table 2 The SSST of NILS under three different environments

\begin{tabular}{|c|c|c|c|c|c|c|c|c|c|c|c|c|c|c|}
\hline $\begin{array}{l}\text { Varieties } \\
\text { /NILs } \\
\text { Environment }\end{array}$ & TN1 & IR24 & $\begin{array}{l}\text { NIL- } \\
\text { BPH4 }\end{array}$ & $\begin{array}{l}\text { NIL- } \\
\text { ВPH9 }\end{array}$ & $\begin{array}{l}\text { NIL- } \\
\text { BPH10 }\end{array}$ & $\begin{array}{l}\text { NIL- } \\
\text { BPH17 }\end{array}$ & $\begin{array}{l}\text { NIL- } \\
\text { BPH18 }\end{array}$ & $\begin{array}{l}\text { NIL- } \\
\text { BPH20 }\end{array}$ & $\begin{array}{l}\text { NIL- } \\
\text { BPH21 }\end{array}$ & $\begin{array}{l}\text { NIL- } \\
\text { BPH26 }\end{array}$ & $\begin{array}{l}\text { NIL- } \\
\text { BPH32 }\end{array}$ & $\begin{array}{l}\text { NIL- } \\
\text { BPH2 + } \\
32\end{array}$ & $\begin{array}{l}\text { NIL- } \\
\text { BPH18+ } \\
32\end{array}$ & $\begin{array}{l}\text { NIL- } \\
\text { BPH9+ } \\
32\end{array}$ \\
\hline Ambient & $\begin{array}{l}9.00 \pm \\
0.00 \mathrm{a}\end{array}$ & $\begin{array}{l}8.20 \pm \\
0.20 \mathrm{ab}\end{array}$ & $\begin{array}{l}6.00 \pm \\
0.91 \\
\text { defg }\end{array}$ & $\begin{array}{l}4.75 \pm \\
0.75 \mathrm{ghi}\end{array}$ & $\begin{array}{l}6.75 \pm \\
0.75 \\
\text { cdef }\end{array}$ & $\begin{array}{l}2.40 \pm \\
0.60 \\
\mathrm{klm}\end{array}$ & $\begin{array}{l}5.67 \pm \\
0.33 \\
\text { efgh }\end{array}$ & $\begin{array}{l}4.00 \pm \\
0.58 \\
\text { hijk }\end{array}$ & $\begin{array}{l}5.33 \pm \\
0.88 \\
\text { fghi }\end{array}$ & $\begin{array}{l}5.67 \pm \\
1.33 \\
\text { efgh }\end{array}$ & $\begin{array}{l}7.33 \pm \\
0.33 \\
\text { bcde }\end{array}$ & $\begin{array}{l}5.67 \pm \\
0.88 \\
\text { efgh }\end{array}$ & $\begin{array}{l}2.67 \pm \\
1.20 \mathrm{klm}\end{array}$ & $\begin{array}{l}2.33 \pm \\
0.88 \\
\mathrm{klm}\end{array}$ \\
\hline 2050 & $\begin{array}{l}9.00 \pm \\
0.00 \mathrm{a}\end{array}$ & $\begin{array}{l}7.78 \pm \\
0.28 \mathrm{bc}\end{array}$ & $\begin{array}{l}6.33 \pm \\
0.88 \\
\text { cdefg }\end{array}$ & $\begin{array}{l}7.00 \pm \\
0.58 \\
\text { bcdef }\end{array}$ & $\begin{array}{l}8.00 \pm \\
0.58 \\
a b c\end{array}$ & $\begin{array}{l}2.33 \pm \\
0.67 \\
\mathrm{klm}\end{array}$ & $\begin{array}{l}7.33 \pm \\
0.33 \\
\text { bcde }\end{array}$ & $\begin{array}{l}5.67 \pm \\
0.33 \\
\text { efgh }\end{array}$ & $\begin{array}{l}7.33 \pm \\
0.67 \\
\text { bcde }\end{array}$ & $\begin{array}{l}6.67 \pm \\
0.67 \\
\text { cdef }\end{array}$ & $\begin{array}{l}6.33 \pm \\
0.67 \\
\text { cdefg }\end{array}$ & $\begin{array}{l}5.67 \pm \\
0.33 \\
\text { efgh }\end{array}$ & $\begin{array}{l}2.33 \pm \\
0.33 \mathrm{klm}\end{array}$ & $\begin{array}{l}2.00 \pm \\
0.58 \mathrm{Im}\end{array}$ \\
\hline 2100 & $\begin{array}{l}9.00 \pm \\
0.00 \mathrm{a}\end{array}$ & $\begin{array}{l}7.44 \pm \\
0.41 \\
\text { bcd }\end{array}$ & $\begin{array}{l}8.00 \pm \\
0.58 \\
a b c\end{array}$ & $\begin{array}{l}7.67 \pm \\
0.67 \\
\text { bcd }\end{array}$ & $\begin{array}{l}8.67 \pm \\
0.33 \mathrm{ab}\end{array}$ & $\begin{array}{l}1.33 \pm \\
0.67 \mathrm{~m}\end{array}$ & $\begin{array}{l}8.00 \pm \\
0.58 \\
a b c\end{array}$ & $\begin{array}{l}5.67 \pm \\
1.33 \\
\text { efgh }\end{array}$ & $\begin{array}{l}7.67 \pm \\
0.88 \\
\text { bcd }\end{array}$ & $\begin{array}{l}5.33 \pm \\
0.33 \\
\text { fghi }\end{array}$ & $\begin{array}{l}4.67 \pm \\
1.33 \\
\text { ghij }\end{array}$ & $\begin{array}{l}6.00 \pm \\
0.58 \\
\text { defg }\end{array}$ & $\begin{array}{l}3.67 \pm \\
1.33 \mathrm{ijkl}\end{array}$ & $\begin{array}{l}3.00 \pm \\
1.15 \\
j k l m\end{array}$ \\
\hline
\end{tabular}

The damage score of $N$. lugens nymphs fed on the TN1, IR24, and NILs based on the standard evaluation method (IRRI 2013). Means followed by different letters differ significantly $(P<0.05)$ 
Table 3 Two-way ANOVA on the SSST result (damage score) of NILs responses to multiple factors

\begin{tabular}{lllll}
\hline Source of variation & Df & SS & F-value & $P$-value \\
\hline Environment $^{\mathrm{a}}$ & 2 & 2.7294 & 1.0190 & 0.3639 \\
Variety $^{\mathrm{b}}$ & 13 & 251.9259 & 14.4706 & $<0.0001^{* * *}$ \\
Environment $X$ Variety $^{*}$ & 26 & 70.0278 & 2.0112 & $0.0058^{* *}$ \\
Residuals & 127 & 170.0778 & & \\
\hline
\end{tabular}

ambient, 2050, 2100

bTN1, IR24, NIL-BPH4, NIL-BPH9, NIL-BPH10, NIL-BPH17, NIL-BPH18, NIL-BPH2O, $\mathrm{NIL}-B P H 21, \mathrm{NIL}-B P H 26, \mathrm{NIL}-B P H 32, \mathrm{NIL}-B P H 2+32, \mathrm{NIL}-B P H 18+32, \mathrm{NIL}-B P H 9+32$ ${ }^{* *} P<0.01$, ${ }^{* * *} P<0.001$

with two $\mathrm{BPH}$ resistance genes maintained their resistance under the environmental changes.

\section{The Antibiosis and Antixenosis effects of NIL-BPH17 \& NIL-BPH20 on N. lugens.}

Based on the results of SSST (Table 2), two NILs that carry a single BPH-resistant gene (NIL-BPH17 and NIL$B P H 20)$ were chosen to test for the antibiosis and antixenosis effects. The honeydew excretion, PGR, nymph survival rate, and oviposition bioassay were used to evaluate the antibiosis effect, while the choice test was used to evaluate the antixenosis effect. Honeydew production was measured using a filter paper with bromocresol green, where the areas of phloem and xylemderived excretions were further calculated. Compared to IR24 and NIL-BPH17, N. lugens showed a lower phloem sap consumption in NIL-BPH17 than in IR24 (Fig. 1a), whereas there was no difference in the xylem sap consumption (Fig. 1b). In the case of NIL-BPH17, there was no environmental effect that was observed on the phloem and xylem sap consumption (Fig. 1). When comparing with IR24 and NIL-BPH20, N. lugens had a lower phloem sap consumption in NIL-BPH2O than in IR24 under the ambient setting (Fig. 2a), while $N$. lugens had a higher phloem sap consumption in NIL-BPH2O than in IR24 under the 2050 setting (Fig. 2a) and no difference was noted under the 2100 setting (Fig. 2a). In addition, there was no difference in the xylem sap consumption (Fig. 2b). In the case of IR24, there was no environmental effect that was observed on the phloem and xylem sap consumption (Fig. 2). In NIL-BPH20, N. lugens had a higher phloem sap consumption under the 2050 and 2100 settings than in the ambient (Fig. 2a). However, there was no environmental effect on the xylem sap consumption in NIL-BPH20 (Fig. 2b). Hence, these results revealed that NIL-BPH17 has a strong inhibitory effect on the $N$. lugens feeding on phloem and would be unaffected by environmental changes, while NIL-BPH2O would lose its ability to inhibit the environmental changes.

Since PGR was one of the parameters used to determine the $N$. lugens growth and development (Du et al.
2009; Qiu et al. 2012), when compared with IR24, NILBPH17 and NIL-BPH20, N. lugens has a lower PGR in NIL-BPH17 than in IR24 and NIL-BPH2O under each environment (Fig. 3). In addition, there was no difference between IR24 and NIL-BPH2O in terms of the $N$. lugens PGR under each environmental setting (Fig. 3). When comparing across the environmental conditions, the $N$. lugens PGR was lower in 2050 and 2100 than in the ambient setting (Fig. 3). These results indicate that the environment in the future would decrease $N$. lugens growth and development. To further understand the antibiosis effect on NILs, the nymph survival rate of $N$. lugens was also measured (Fig. 4). Based on the 9-day results, the $N$. lugens nymph survival rate was affected by the environment, variety, and the interaction between environment and variety (Table 4).

Within the NILs, the nymph survival rate of $N$. lugens feeding on NIL-BPH17 was lower than that of $N$. lugens feeding on IR24 and NIL-BPH2O $(P<0.001)$ (Table 4$)$, while in terms of the environments, the $N$. lugens nymph survival rate was lower at 2100 than in the ambient and 2050 settings $(P<0.001)$ (Table 4$)$, which indicates that the environment of 2100 may not be suitable for $N$. lugens nymphs. Furthermore, the nymph survival rate of $N$. lugens on NIL-BPH17 was different from that of IR24 and NIL-BPH2O under the environmental changes (Fig. 5). When the atmospheric temperature and carbon dioxide concentrations were increased, NIL-BPH17 had a stronger resistance against the $N$. lugens nymphs (Fig. 5), in which NIL-BPH2O showed the same trend as IR24 (Fig. 5).

The oviposition bioassay was examined for $N$. lugens female fecundity and egg hatchability, where $N$. lugens females showed lower fecundity on NIL-BPH17 than on IR24 and NIL-BPH20, except under 2100 (Fig. 6a). Within the NILs, there was no effect on the environmental changes (Fig. 6a), while egg hatchability was affected by environmental changes, where the egghatching rate was lower than 2100 than ambient and 2050 (Fig. 6b). There was also no difference among the three varieties (Fig. 6b), indicating that $N$. lugens fecundity is determined by the host plants, which would be unaffected by the environment. However, the environment was the major factor influencing hatchability. In addition to the antibiosis effect, the choice test was tested to understand the antixenosis effect on the NILs. Compared to IR24 and NIL-BPH17, more N. lugens nymphs chose IR24 instead of NIL-BPH17, starting from $24 \mathrm{~h}$ to $120 \mathrm{~h}$ under the ambient conditions (Fig. 7a). Under 2050 and 2100, N. lugens nymphs preferred IR24 at $6 \mathrm{~h}$ after the experiment (Fig. $7 \mathrm{~b}$ and c). However, compared to IR24 and NIL-BPH20, there was no difference under the ambient and 2100 conditions (Fig. 8a and c). Under the 2050 conditions, $N$. lugens nymphs preferred IR24 
(a)

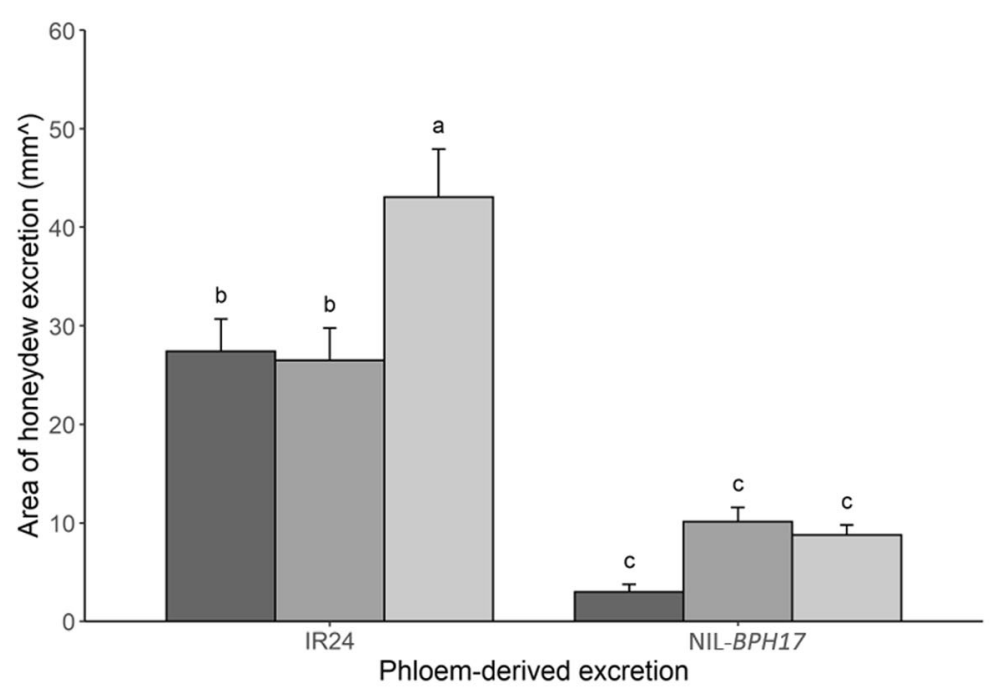

(b)

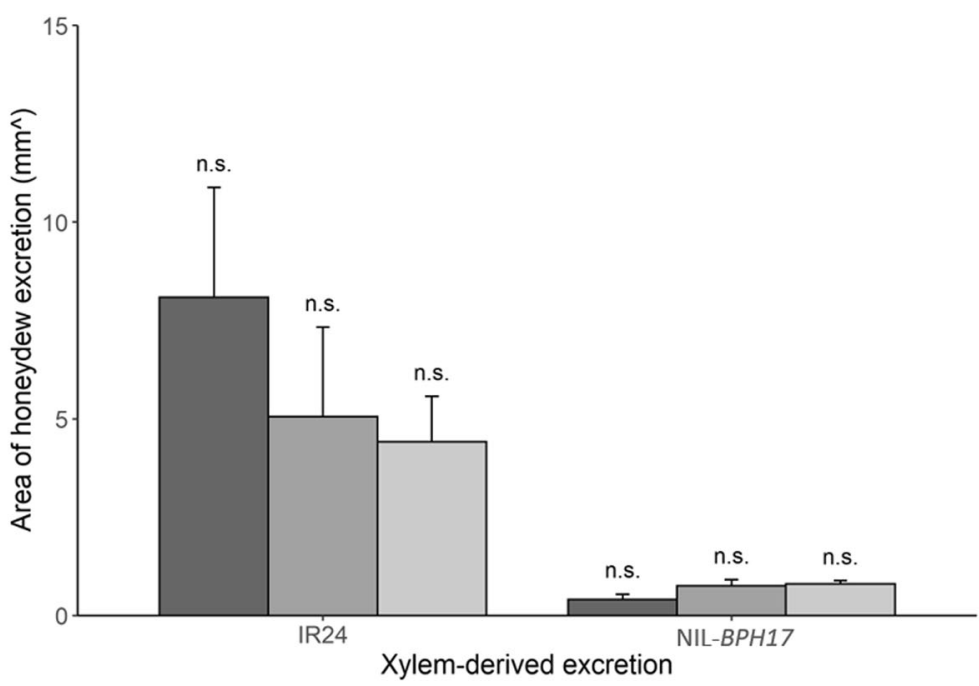

Fig. 1 Areas of honeydew excretion of N. lugens female feeding on IR24 and NIL-BPH17 under different environments. a Phloem-derived excretion. bxylem-derived excretion. Means in each column followed by a different letter differ significantly $(P<0.05)$

over NIL-BPH2O at $3 \mathrm{~h}$ after the experiment, except at $96 \mathrm{~h}$ (Fig. 8b), indicating that NIL-BPH17 had a strong repellence as the environmental changed, whereas NIL$B P H 2 O$ had a strong repellence only under the 2050 conditions.

\section{Discussion}

The results of this study revealed that the BPH resistance genes would be affected by the environmental changes, in which NILs are valuable genetic resources for identifying potential resistance genes that can resist environmental changes in the decades to come. This study identified NIL-BPH17 and NIL-BPH2O, which maintained a low damage score under environmental changes (Table 2) and that $N$. lugens had different responses to those two NILs (Figs. 1, 2, 3, 5, 6a, 7 and 8). The inhibitory effect of NIL-BPH17 on the N. lugens growth and development was unaffected by climate change, whereas NIL-BPH2O may reduce its resistance during the environmental changes.

The resistance of $B P H 17$ and $B P H 2 O$ was originally screened by the SSST (Rahman et al. 2009; Sun et al. 2005), in which the BPH17 gene is located on chromosome $4 \mathrm{~S}$ from the traditional rice germplasm, Rathu Heenati (Sun et al. 2005). BPH17 was cloned and its function was identified as a cluster of three lectin 
(a)
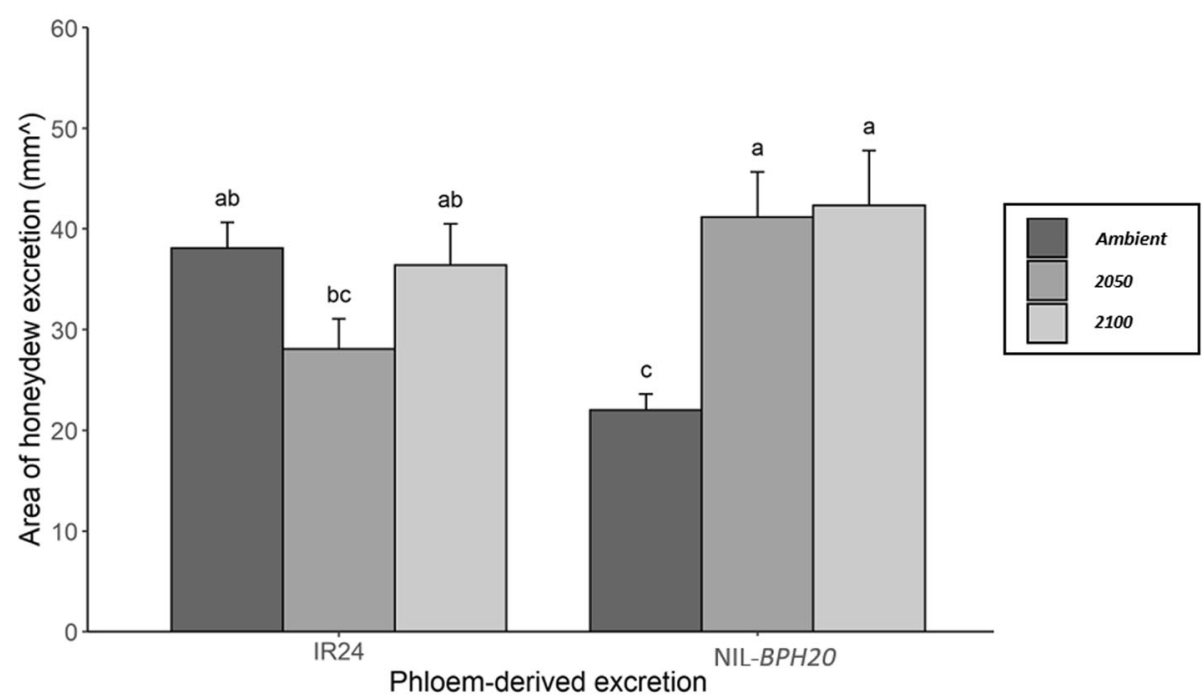

(b)

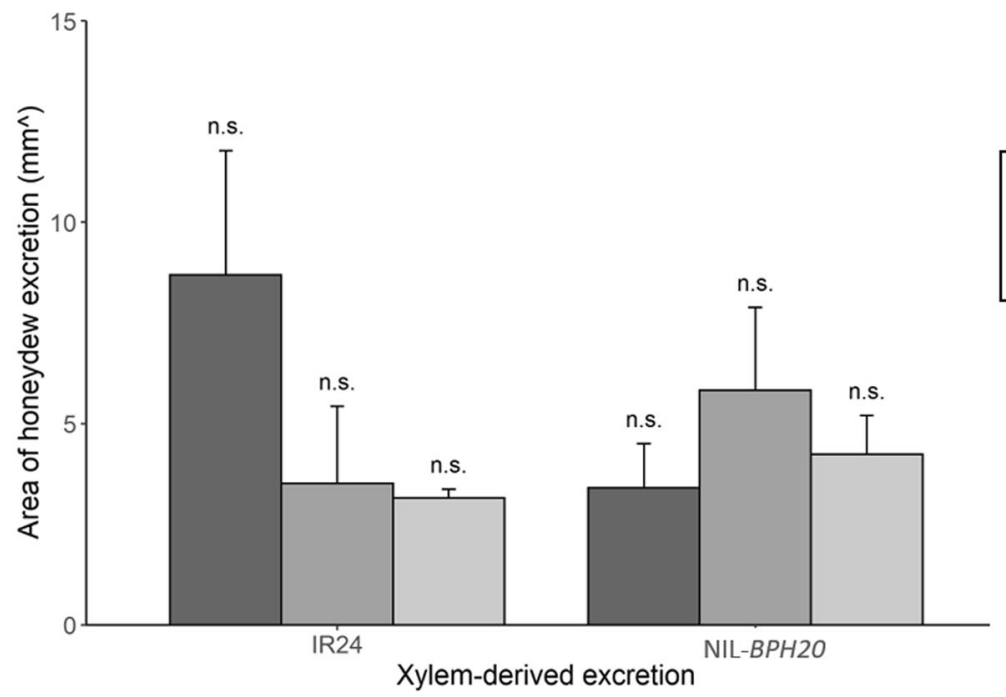

Fig. 2 Areas of honeydew excretion of N. lugens female feeding on IR24 and NIL-BPH2O under different environments. a Phloem-derived excretion. bxylem-derived excretion. Means in each column followed by a different letter differ significantly $(P<0.05)$

receptor kinases (OsLecRK1-OsLecRK3) (Liu et al. 2015). These lectin receptor kinases are localized on the plasma membrane of the vascular bundles of the leaf sheath cells (Liu et al. 2015), where three lectin receptor kinases show distinct expression profiles after $N$. lugens feeding (Liu et al. 2015). In our study, NIL-BPH17 showed strong resistance (ambient: 2.4; 2050: 2.3; and 2100: 1.3 ) in the SSST experiment. These results were consistent with another NIL-BPH17 study under the ambient temperature condition (Nguyen et al. 2019). In addition, the NIL-BPH17 gene exhibited a strong inhibitory effect on several $N$. lugens parameters, such as in the honeydew assay, PGR, survival rate, fecundity, and choice tests, where our results were consistent with those of (Liu et al. 2015). Surprisingly, in the choice test assay in our study and in the study by (Liu et al. 2015) plants carrying BPH17 had a lower number of $N$. lugens after $24 \mathrm{~h}$ of ambient conditions, indicating that the BPH17 gene may have strong insect repellent properties. Furthermore, this repellent effect became stronger under the environmental changes, in which the profile of the volatile organic compounds on NIL-BPH17 should be further examined in terms of their antixenosis effect in the future. Based on our study, the results indicate that BPH17 may have strong antibiotic and antixenosis effects. 


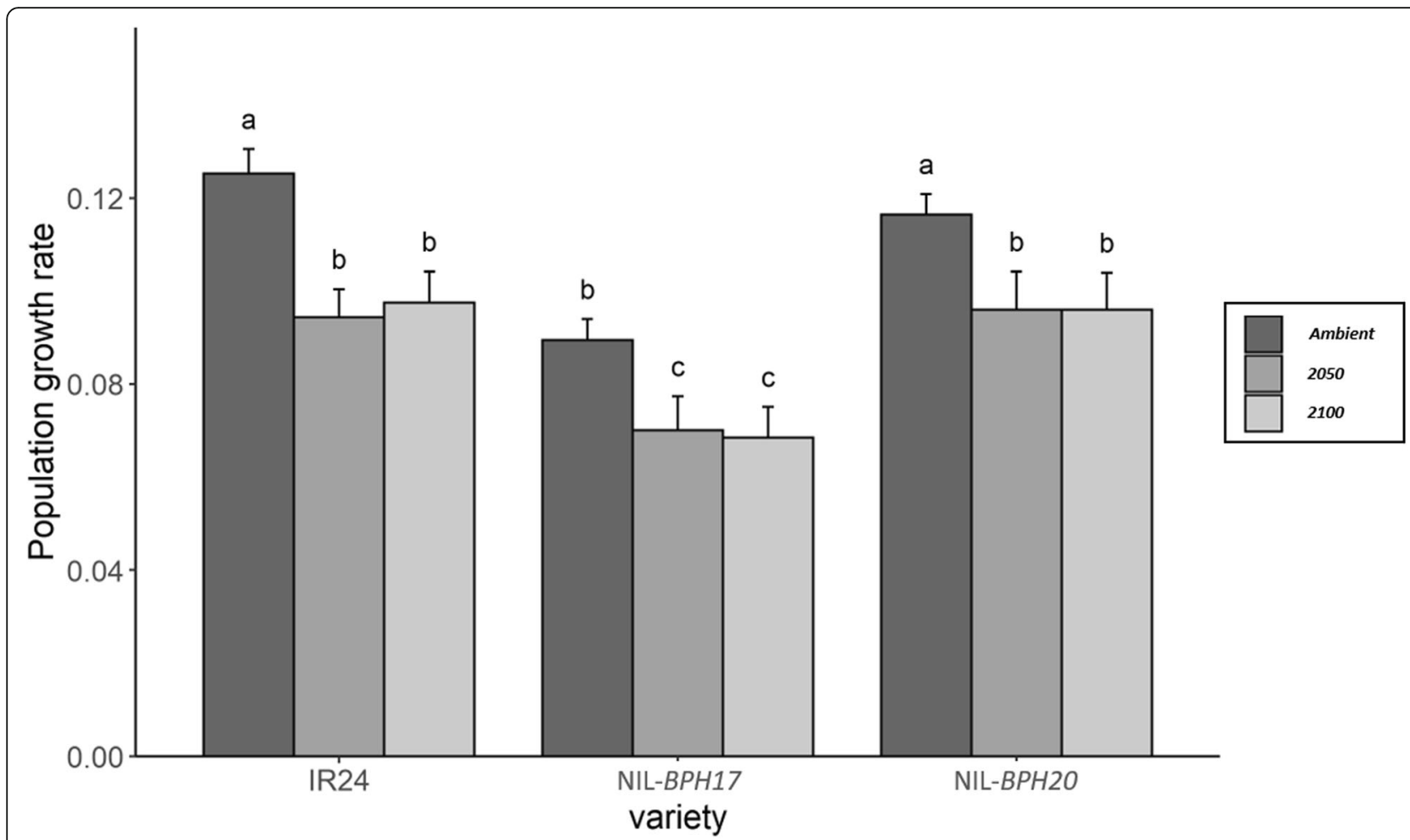

Fig. 3 The population growth rate of N. lugens nymphs feeding on IR24 and NILs under different environments. a IR24 and NIL-BPH17. b IR24 and NIL-BPH2O. Means in each column followed by a different letter differ significantly $(P<0.05)$

The BPH2O gene derived from O. miniuta is also located on chromosome 4 (Rahman et al. 2009). However, the function of $\mathrm{BPH} 2 \mathrm{O}$ is unclear. In our study, NILBPH2O showed consistent resistance (ambient: 4.0; 2050: 5.7; and 2100: 5.7) in the SSST experiment, but not in the other BPH-relative assays under climate change. Since the SSST assay is a traditional screening method to identify potential BPH-resistant plants, it can mix the antixenosis (non-preference), antibiosis, and tolerance effects. Thus, it would be difficult to characterize the host plant resistance category based on the SSST. N. lugens females produced a small amount of phloemderived excretion by feeding on NIL-BPH2O under the ambient conditions, where this honeydew bioassay result was consistent with a previous report (Jiang et al. 2018). However, NIL-BPH2O lost its inhibitory effect under the environmental changes. In addition, BPH2O did not inhibit several $N$. lugens parameters, such as the PGR, survival rate, fecundity, and hatchability. Moreover, it has been reported that NIL-BPH2O and the susceptible donor, Taichung 65, showed similar $N$. lugens adult mortality with two $N$. lugens colonies (Nguyen et al. 2019). Thus, these results indicate that NIL-BPH2O may contain $N$. lugens tolerance and weak antixenosis and antibiotic effects.

Climate change has dramatically changed our society, where it impacts crop production and food and nutrition quality. It is predicted that increasing atmospheric $1{ }^{\circ} \mathrm{C}$ would reduce $3.2 \%$ crop production in rice (Zhao et al. 2017). Planting insect-resistant varieties is an IPM strategy to reduce the yield loss caused by insect infestation and to reduce pesticide usage. However, in our study, several $\mathrm{BPH}$ resistance genes (BPH4, BPH9, BPH10, $B P H 18, B P H 21, B P H 21, B P H 32$, and $B P H 2+32)$ would lose their resistance due to climate change. In addition, another three BPH resistant varieties, IR26 (BPH1), IR36 $(B P H 2)$ and IR62 $(B P H 26+32)$, would lose the resistance under elevated temperature (Horgan et al. 2021a; Wang et al. 2010). These results imply that we need to use these insect-resistance traits/genes very carefully to prevent the development of a loss-of-function effect on the insect-resistant varieties in the future. Furthermore, even though NIL-BPH2O showed a consistent damage score under the environmental changes, $N$. lugens females produced more phloem-derived honeydew on NIL-BPH20, implying that $N$. lugens may feed more phloem sap to obtain more nutrients to detoxify the plant's resistance in the future. In addition, $N$. lugens showed similar growth parameters under the ambient and 2050 conditions (Fig. 6). Thus, the environmental conditions of 2050 will be suitable for N. lugens. However, under the environmental conditions of 2100, $N$. lugens would have a lower survival rate and hatchability. This result was consistent with the studies showed that 


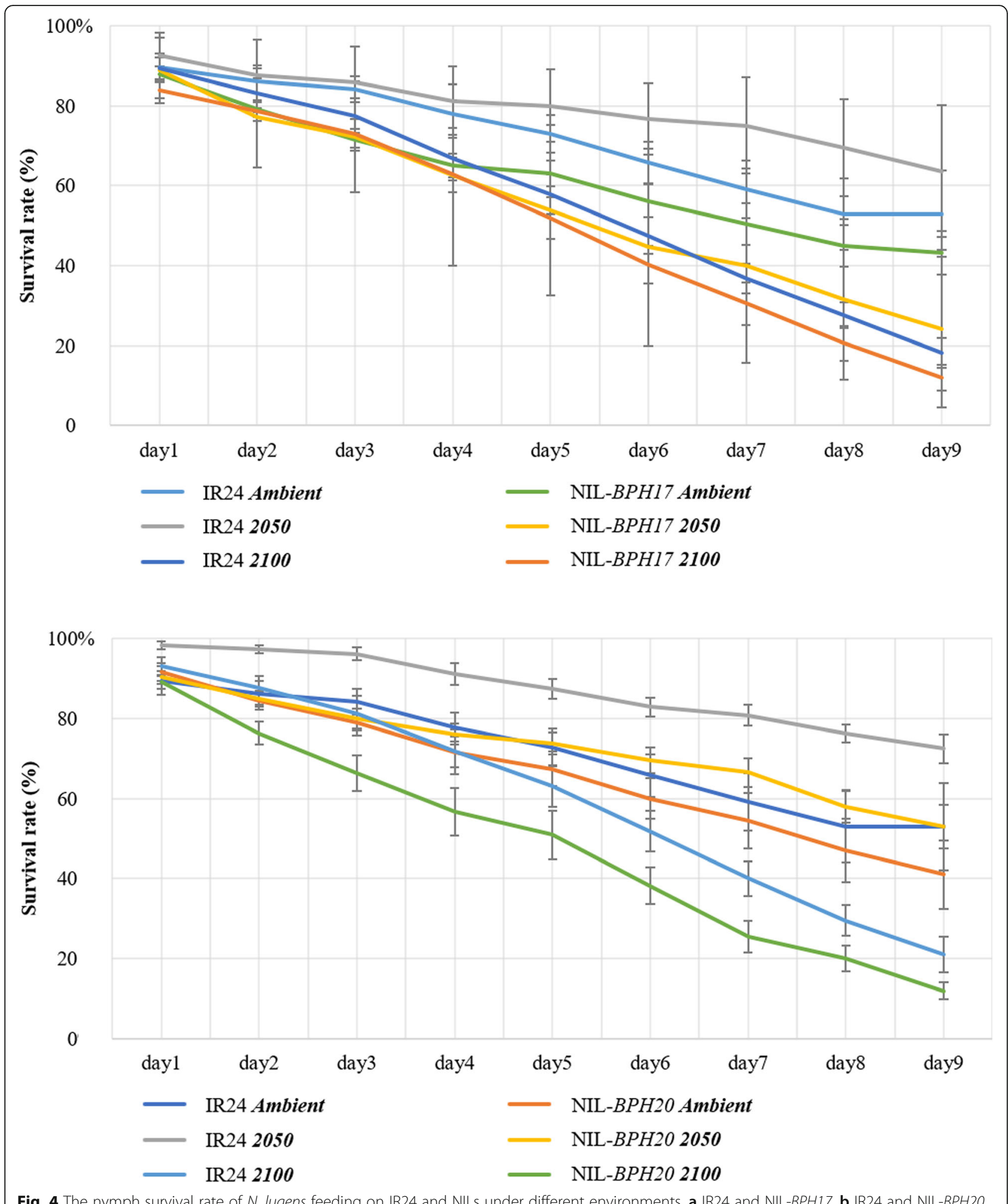

Fig. 4 The nymph survival rate of N. lugens feeding on IR24 and NILs under different environments. a IR24 and NIL-BPH17. b IR24 and NIL-BPH2O

high temperature $\left(34-35^{\circ} \mathrm{C}\right.$, the prediction temperature of 2100) would greatly reduce $N$. lugens survival rate (Horgan et al. 2020; Horgan et al. 2021a; Horgan et al. 2021b; Wang et al. 2010).
Pyramided genes are a strategy to input multiple genes into one plant to synergize the resistance level, which has been used to demonstrate durable insect resistance (Horgan et al. 2019). In our study, two NILs with two 
Table 4 Two-way ANOVA on the day 9 survival rate of N. lugens nymphs feeding on IR24, NIL-BPH17 and NIL-BPH2O responses to multiple factors

\begin{tabular}{lllll}
\hline Source of variation & Df & SS & F-value & $P$-value \\
\hline Environment $^{\mathrm{a}}$ & 2 & 0.6664 & 9.3726 & $0.0002^{* * *}$ \\
Variety $^{\mathrm{b}}$ & 2 & 1.0233 & 14.3924 & $<0.0001^{* * *}$ \\
Environment X Variety & 4 & 0.5429 & 3.8176 & $0.0063^{* *}$ \\
Residuals & 97 & 3.4483 & & \\
\hline
\end{tabular}

${ }^{\mathrm{a} A m b i e n t, 2050,2100}$

' IR24, NIL-BPH17, NIL-BPH2O

${ }^{* *} P<0.01, * * * P<0.001$

pyramided genes (NIL-BPH18 + 32 and NIL-BPH9 + 32) not only showed lower damage scores than NILs with a single $\mathrm{BPH}$ gene $(\mathrm{BPH} 9,18$, and 32$)$ in the ambient environment, but also maintained a consistent resistance under the environmental changes. Thus, the gene pyramiding strategy not only enhances the resistance but also maintains the resistance ability under climate change. In addition, the combination of resistance genes with different protein functions would have a synergistic effect. In our study, it was revealed that each $\mathrm{BPH}$ resistance gene (BPH9, 18, and 32) would have an impact on the environmental changes. $B P H 2,9$, and 18 are the three of the four alleles of the same locus, which encode a protein with a CC-NB-NB-LRR domain (Zhao et al. 2016), while $B P H 32$ encodes an unknown short consensus repeat domain (Ren et al. 2016). By using gene pyramiding, a single resistance gene that would have an impact on climate change would maintain/enhance its resistance under the environmental changes. Among the three pyramided gene combinations, the synergistic effect consisted of $B P H 18+32=B P H 9+32>B P H 2+32$. Thus, it indicates that the alleles at the same locus may have different synergistic effects. Hence, this study provides important contributions to the integration of IPM, where $\mathrm{BPH}$ resistance genes may have a strong impact on the environmental changes. By using pyramided genes, the resistance level of the rice plants would be both enhanced and maintained under climate change. Furthermore, the understanding of the impact of the resistance genes under the environmental changes would benefit future host-plant resistance breeding programs that could be conducted on rice against climate change.

\section{Conclusions}

A set of NILs carrying with $\mathrm{BPH}$ resistance genes were investigated the responses under climate change impact. Most of tested NILs had changed their resistance level under the environmental changes. In addition, NIL$B P H 17$ would maintain its inhibitory effect against $N$. lugens under environmental changes, while NIL-BPH2O would lose its ability during the environmental changes. These results provide valuable information for future host-plant resistance breeding programs.

\section{Materials and Methods}

Environmental Chamber Settings

Based on the IPCC prediction (Stocker et al. 2013), three environmental settings in this study were set up as follows: (1) Ambient: $30^{\circ} \mathrm{C} / 25^{\circ} \mathrm{C}$ (light/dark), $\mathrm{CO}_{2}$ concentration of $500 \mathrm{ppm}$; (2) the prediction environment in

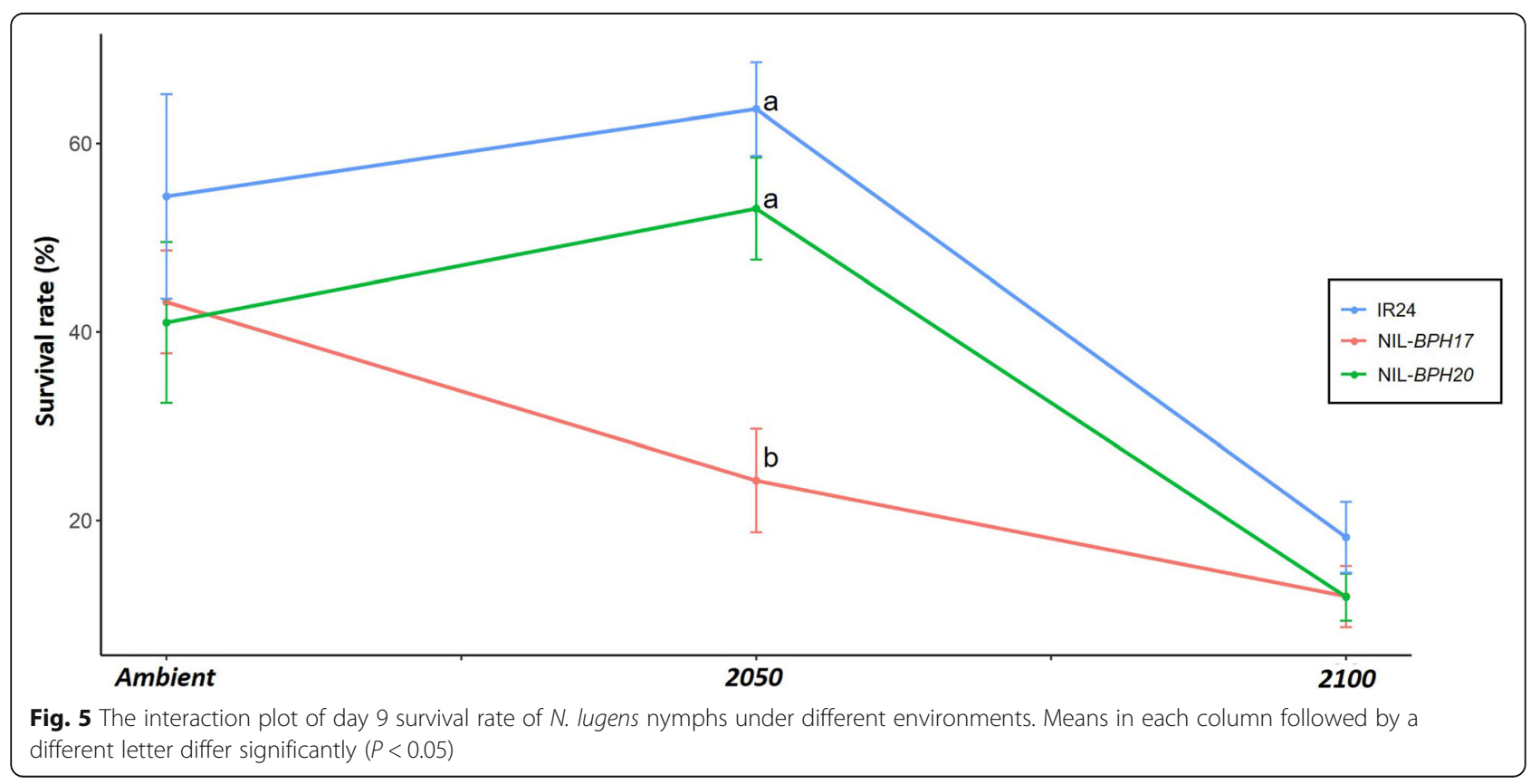


(a)

BPH female fecundity

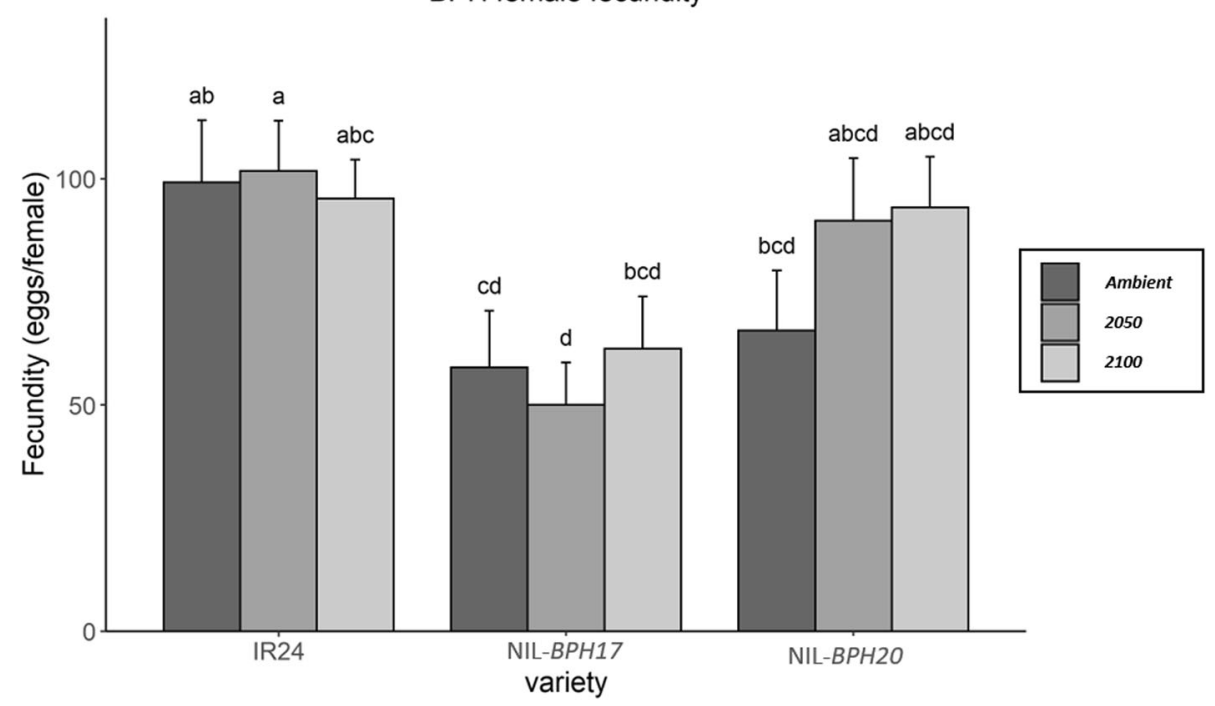

(b)

Hatchability of eggs

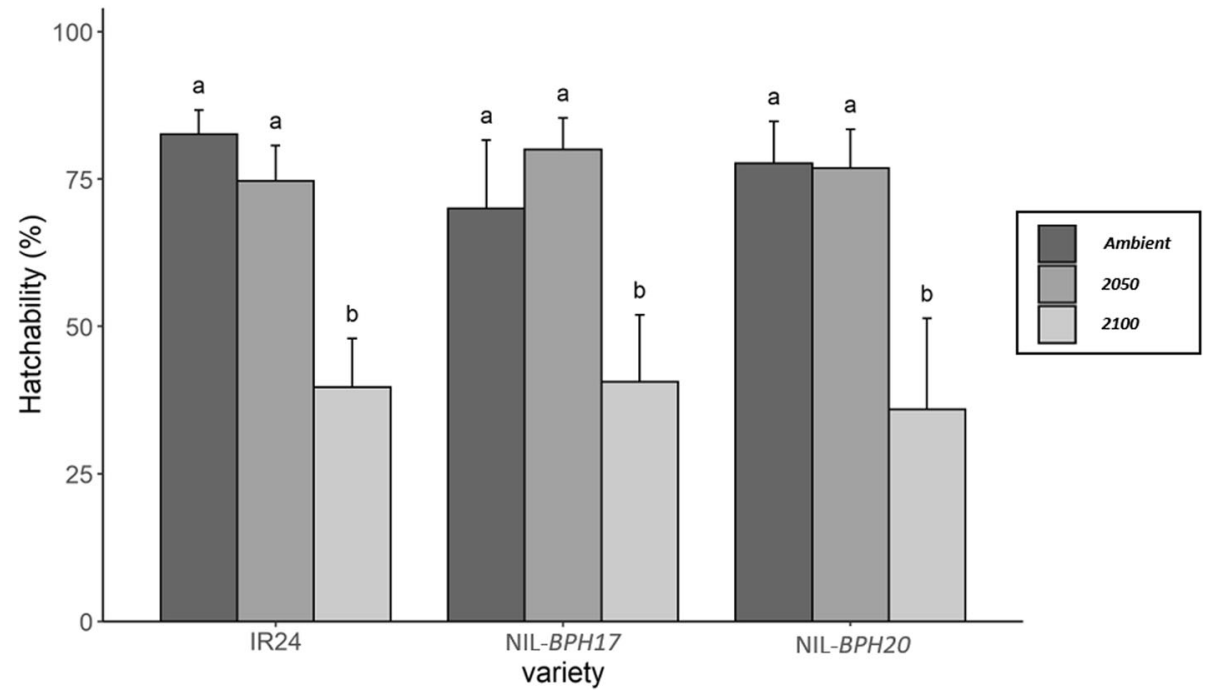

Fig. 6 The N. lugens female fecundity and hatchability of IR24 and NILs under different environments. a Fecundity. b Hatchability. Means in each column followed by a different letter differ significantly $(P<0.05)$

the year 2050: $32^{\circ} \mathrm{C} / 27^{\circ} \mathrm{C}(\mathrm{L} / \mathrm{D}), \mathrm{CO}_{2}$ concentration of $600 \mathrm{ppm}$; (3) and the prediction environment in the year 2100 as well as $35^{\circ} \mathrm{C} / 30^{\circ} \mathrm{C}$ (L/D) and a $\mathrm{CO}_{2}$ concentration of $1000 \mathrm{ppm}$. The growth chambers were set to a $12: 12 \mathrm{~h}$ cycle (L:D) under a relative humidity of $55 \pm 5 \%$, while the temperature and $\mathrm{CO}_{2}$ concentration in the aforementioned settings were further measured as Ambient: $29.67^{\circ} \mathrm{C} \pm$ $0.02{ }^{\circ} \mathrm{C} / 24.69^{\circ} \mathrm{C} \pm 0.01{ }^{\circ} \mathrm{C}(\mathrm{L} / \mathrm{D})$ and a $\mathrm{CO}_{2}$ concentration of $531.81 \pm 0.58 \mathrm{ppm} ; \quad 2050: \quad 31.64{ }^{\circ} \mathrm{C} \pm$ $0.003{ }^{\circ} \mathrm{C} / 26.65{ }^{\circ} \mathrm{C} \pm 0.0001{ }^{\circ} \mathrm{C}(\mathrm{L} / \mathrm{D})$ and a $\mathrm{CO}_{2}$ concentration of $612.19 \pm 0.34 \mathrm{ppm}$; as well as 2100 : $34.26{ }^{\circ} \mathrm{C} \pm 0.035{ }^{\circ} \mathrm{C} / 31.95^{\circ} \mathrm{C} \pm 0.015^{\circ} \mathrm{C}$ (L/D) and a $\mathrm{CO}_{2}$ concentration of $1013.82 \pm 30.29 \mathrm{ppm}$.

\section{Plant Material}

The 12 NILs, of which nine and three NILs carry one and two BPH resistance genes, respectively (Table 1), which were originally obtained from IRRI (Jena et al. 2017). IR24 was obtained from the National Plant Genetic Resources Center at the Taiwan Agricultural Research Institute (TARI), Council of Agriculture (COA), Taiwan. The susceptible check Taichung Native 1 (TN1) for the SSST was obtained from the Taichung District Agricultural Research and Extension Station, COA, Taiwan. Seeds were surfacesterilized with $2 \%(\mathrm{v} / \mathrm{v}) \mathrm{NaOCl}$ for $30 \mathrm{~min}$ and further washed with distilled water for $10 \mathrm{~min}$. Then, the seeds were germinated on water-moistened paper towels for 2 days under a dark environment at $30^{\circ} \mathrm{C}$. 
(a)

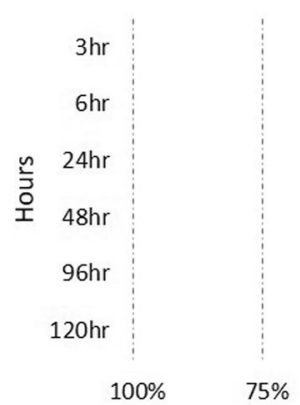

(b)

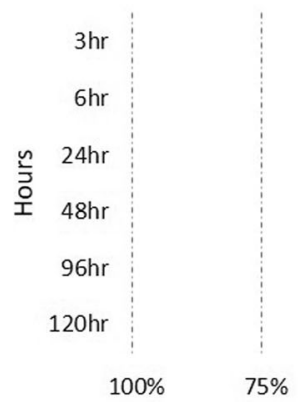

(c)

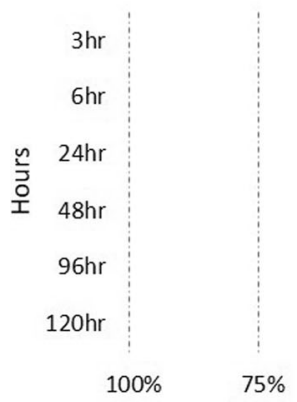

Ambient $\mathrm{BPH}$ choice test

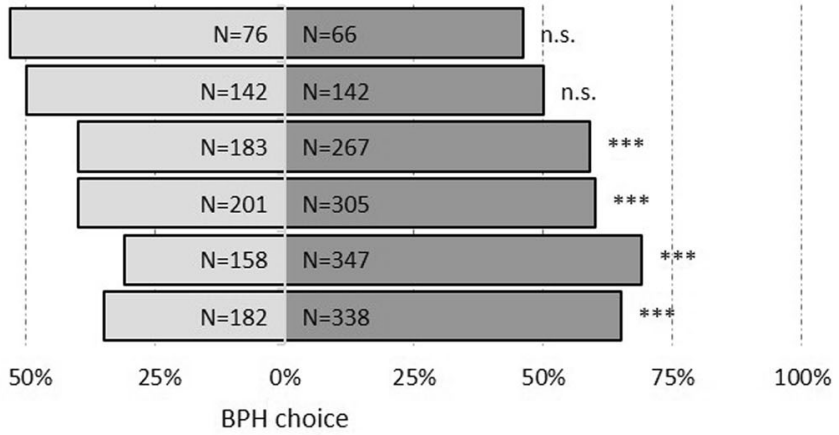

口NIL-BPH17 ㅁIR24

$2050 \mathrm{BPH}$ choice test

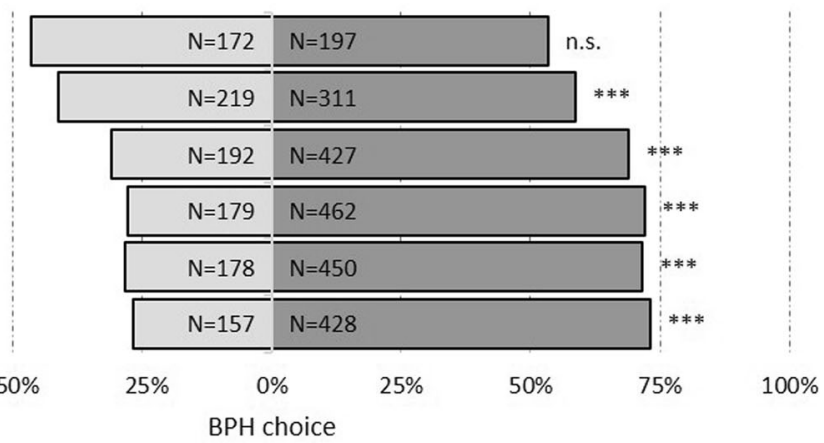

$\square$ NIL-BPH17 口IR24

\section{$2100 \mathrm{BPH}$ choice test}

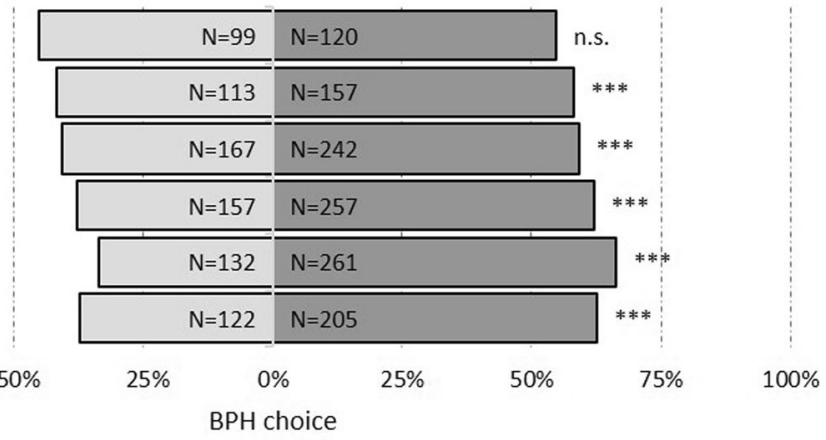

口NIL-BPH17 IR24

Fig. 7 The choice test of N. lugens nymphs on IR24 and NIL-BPH17 under different environments. a Ambient. b 2050. c 2100. Asterisks indicate differences between IR24 and NIL-BPH17 as: ${ }^{* *} P<0.001$; n.s. means non-significant

\section{Insect Rearing}

The $N$. lugens biotype 1 colony was originally obtained from the Chiayi Agricultural Experiment Station, TARI, COA, Taiwan, in which the $N$. lugens colonies were mass-reared on the TN1 seedlings in fine-meshed insect cages (BugDorm-4, Megaview, Taichung, Taiwan). The TN1 seedlings were placed in trays and treated with soluble fertilizer consisting of 120,40 , and $60 \mathrm{~kg} / \mathrm{ha}$ of nitrogen $(\mathrm{N})$, phosphorus $(\mathrm{P})$ and potassium (K) until the 4-leaf stage, which was 
(a)

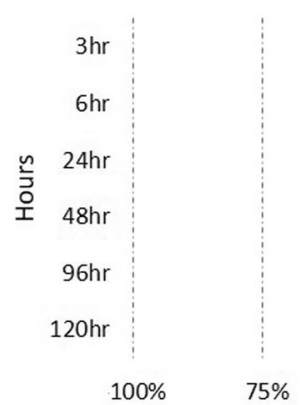

(b)

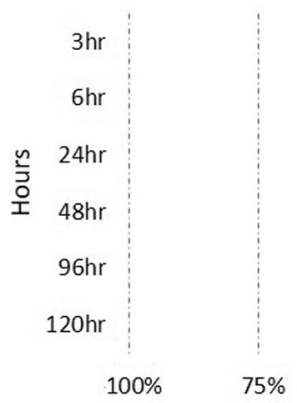

(c)

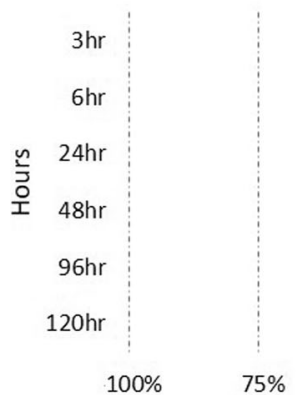

Ambient BPH choice test

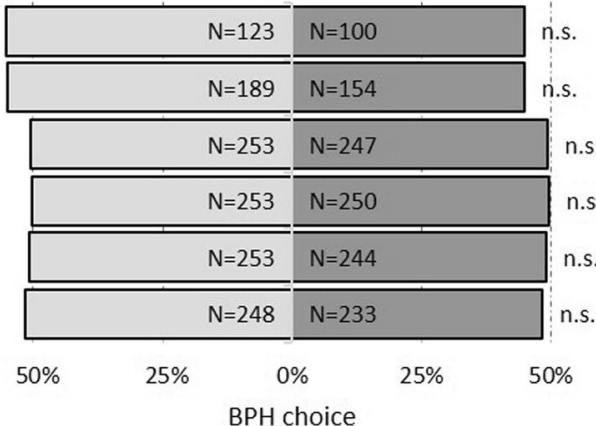

口NIL-BPH20 口IR24

2050 BPH choice test

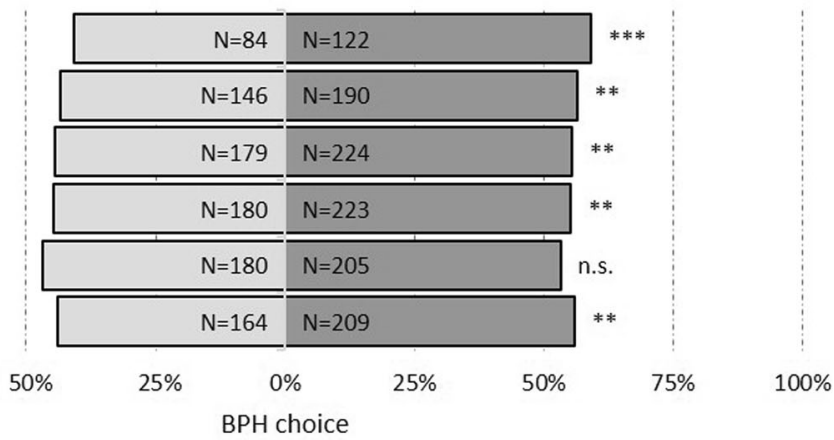

口NIL-BPH2O ㅁIR24

\section{BPH choice test}

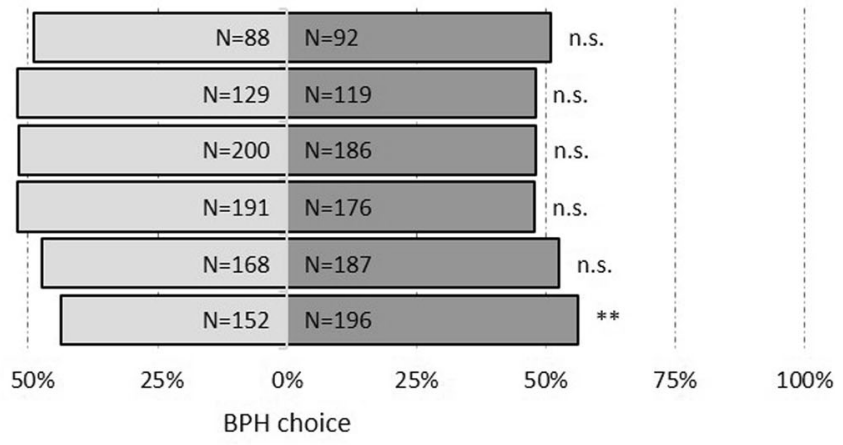

口NIL-BPH20 ㅁR24

Fig. 8 The choice test of N. lugens nymphs on IR24 and NIL-BPH2O under different environments. a Ambient. b 2050. c 2100. Asterisks indicate differences between IR24 and NIL-BPH2O as: ${ }^{* *} P<0.01$; ${ }^{* *} P<0.001$; n.s. means non-significant

periodically changed to maintain the $N$. lugens colonies. For this study, the $N$. lugens colonies were reared separately in three different environmental chambers reflecting the ambient, 2050, and 2100 environments, which were maintained for at least two generations prior to the experiment. Each N. lugens colony was only used for the corresponding environmental setting. After the experiment, the insects were not used to maintain the colony or used in other experiments. 


\section{The Standard Seed-Box Screening Test (SSST)}

In this study, the SSST was used to evaluate the plant's resistance against $N$. lugens. Briefly, 20 seeds of each NIL, IR24, and susceptible check TN1 were sown in rows. Then, 14 days after sowing, the seedlings were infested with 2nd to 3 rd instar $N$. lugens nymphs at a density of 10 nymphs per seedling. The damage levels of the tested plants were evaluated based on the standard evaluation system (IRRI 2013) when the susceptible TN1 plants were declared dead. This experiment was repeated three times in each environmental setting.

\section{Honeydew Excretion Test}

The amount of honeydew in the $N$. lugens feeding on the tested plants was used for the antibiosis resistance test. Because of the unique $N$. lugens-feeding behavior, the honeydew excretion can be determined by the method of using filter paper that was treated with bromocresol green (Pathak and Heinrichs 1982). The NILBPH17, NIL-BPH20, and the background variety IR24 were chosen for the honeydew excretion test. Briefly, seedlings were transferred into plastic pots with a 64 $\mathrm{mm}$ base diameter, a $95 \mathrm{~mm}$ aperture diameter, and a height of $165 \mathrm{~mm}$ that contained paddy soil and was treated with a soluble fertilizer. After 30 days of germination, the branches that emerged from the main tiller of the tested plants were removed and a plastic layer with a hole in the middle was placed on top of the plants' soil surface. The filter paper that was treated with $0.1 \%$ bromocresol green (Alfa Aesar, Haverhill, MA, USA) was placed on top of the plastic layer, covered with a plastic cover that had a hole in the middle, and secured with a cotton plug. One female gravid $N$. lugens with $2 \mathrm{~h}$ starvation treatment was placed on the plant to allow its feeding for $24 \mathrm{~h}$. Next, the filter papers were collected and scanned. Due to the different chemical properties of the phloem and xylem, the bromocresol green indicates the phloem-derived excretion as blue-rimmed spots and the xylem-derived excretion as transparent-rimmed spots (Auclair et al. 1982; Kimmins 1989). The area of each spot was measured using the ImageJ software (Rasband 1997). The sample size (n) of the replicates $(\mathrm{N})$ in each environmental setting reflecting the NIL-BPH17 and IR24 experiment as well as the NIL-BPH2O and IR24 experiment, which both consisted of the ambient, 2050, and 2100 environmental settings of: $N=3$ and $n=8-12$, respectively.

\section{$N$. lugens Population Growth Rate (PGR)}

The seedlings were transferred into plastic pots that contained paddy soil and were treated with a soluble fertilizer. At 35 days after germination, the branches, with the exception of the main tiller of the tested plants, were removed. Then, 10 weighted 2 nd instar $N$. lugens nymphs were placed on the plant with a plastic cover that had a hole in the middle and was secured with a cotton plug. After the 4-day infestation, the surviving $N$. lugens nymphs were counted and weighed, in which the formula for the PGR was as follows (Edwards 2001; Klingler et al. 2005):

\section{PGR $=\log ($ Survived $N$.lugens nymph weight/Survived $N$.lugens nymph number $)$ $-\log ($ Total $N$. lugens nymph weight/total $N$.lugens nymph number)}

The sample size $(\mathrm{n})$ of the replicates $(\mathrm{N})$ in each environmental setting in the NIL-BPH17, NIL-BPH2O, and IR24 experiment included $N=3$ and $n=4-5$ across all three environmental settings.

\section{N. Lugens Survival Rate}

The seedlings were transferred into plastic pots that contained paddy soil and were treated with the soluble fertilizer. At 30 days after germination, the branches, with the exception of the main tiller of the tested plants were removed. Then, ten $3 \mathrm{rd}$ instar $N$. lugens nymphs were placed on the plant with a plastic cover that had a hole in the middle and was secured with a cotton plug. The survival rate of $N$. lugens nymphs was recorded until 9 days after infestation. The sample size (n) of the replicates $(\mathrm{N})$ in each environmental setting for the NIL$B P H 17$, NIL-BPH2O, and IR24 experiment included $\mathrm{N}=$ 3 and $n=2-5$ across all three environmental settings.

\section{N. Lugens Choice Test}

The choice test was used as the non-preference test, where five plants per IR24, NIL-BPH17, IR24, and NILBPH2O line were cross-planted in pots of a $160 \mathrm{~mm}$ base diameter, a $200 \mathrm{~mm}$ aperture diameter, and a height of $222 \mathrm{~mm}$ that contained paddy soil and were treated with a soluble fertilizer. A total of 100 3rd instar nymphs were placed on a Petri dish that was transferred to the center of the pot when the plants were at the 4-leaf stage, which were covered with fine-meshed insect cages (BugDorm-4, Megaview, Taichung, Taiwan). After opening the top of the Petri dish, the number of nymphs on each plant was counted at 3, 6, 24, 48, 96, and $120 \mathrm{~h}$, where the total number of nymphs on NIL-BPH17 \& IR24 and NIL-BPH2O \& IR24 were calculated. The sample size (n) in each environmental setting for the NILBPH17 and IR24 experiment consisted of the ambient: $n=600 ; 2050: n=900$; and 2100: $n=500$, while in the case of the NIL-BPH2O and IR24 experiment, the values included the ambient: $\mathrm{n}=600 ; 2050: \mathrm{n}=600$; and 2100: $n=500$.

\section{N. Lugens Fecundity and the Hatchability of Eggs}

The seedlings were transferred into plastic pots that contain paddy soil and were treated with a soluble 
fertilizer. At 30 days after germination, the branches, with the exception of the main tiller of the tested plants, were removed. One female gravid $N$. lugens and one male $N$. lugens were transferred to the plant with a plastic cover that had a hole in the middle and was secured with a cotton plug. Adult insects were removed after the fifth day of the experiment, while the newly hatched nymphs were further counted for the following 10 days. At the end of the experiment at 45 days after germination, the leaf sheath was cut and counted to obtain the number of non-hatched eggs. The sample size (n) of the replicates $(\mathrm{N})$ in each environmental setting for the NIL$B P H 17$, NIL-BPH2O, and IR24 experiment included $N=$ 3 and $n=2-6$ across all three environmental settings.

\section{Statistical Analysis}

For the SSST, the data were analyzed using a two-way analysis of variance (ANOVA). the honeydew test, PGR, fecundity, and the hatchability of eggs were analyzed using a one-way ANOVA. The least significant difference test was used to test for differences at $P<0.05$, while the choice test was analyzed using the $z$-test. All data were analyzed using R software (v3.5.0) (R Core Team 2013).

\section{Abbreviations}

BPH: Brown planthopper; $\mathrm{CO}_{2}$ : Carbon dioxide; IPCC: The Intergovernmental Panel on Climate Change; IPM: Integrated pest management; IRRI: International Rice Research Institute; NIL: Near-isogenic line; SST: The standard seed-box screening test

\section{Acknowledgements}

We thank Dr. Chung-Ta Liao (Taichung District Agricultural Research and Extension Station) for generously providing TN1 seeds. The IR24 seeds were obtained from the National Plant Genetic Resources Center, Taiwan Agricultural Research Institute, Taiwan. We are grateful to Dr. Yung-Fen Huang for suggestions on how to improve the manuscript.

\section{Authors' contributions}

WC conceived the project; YK and WC designed the experiments; YK, YF, and SL performed the experiments; YK, YF, and ST analyzed the data; and YK, ST, $\mathrm{ZY}, \mathrm{CL}, \mathrm{SHH}, \mathrm{SLH}, \mathrm{K}$, and WC wrote the manuscript. The author(s) read and approved the final manuscript.

\section{Funding}

This work was supported by grants from the Ministry of Science and Technology, Taiwan, Grant Number 107-2311-B-002-018-MY3 (W-P. C.) and National Taiwan University, Taiwan, Grant Number NTU-109 L7864 (W-P. C.).

\section{Availability of data and materials}

The datasets used and/or analyzed during the current study are available from the corresponding author on reasonable request.

\section{Declarations}

Ethics approval and consent to participate Not applicable.

\section{Consent for publication}

Not applicable.

\section{Competing interests}

The authors declare that the research was conducted in the absence of any commercial or financial relationships that could be construed as a potential conflict of interest.

\section{Author details}

'Department of Agronomy, National Taiwan University, Taipei 10617, Taiwan. ${ }^{2}$ Crop Improvement Division, Taoyuan District Agricultural Research and Extension Station, Council of Agriculture, Taoyuan City 32745, Taiwan. ${ }^{3}$ Crop Science Division, Taiwan Agricultural Research Institute, Council of Agriculture, Taichung City 41362, Taiwan. ${ }^{4}$ Department of Plant Protection, Chiayi Agricultural Experiment Station, Taiwan Agricultural Research Institute, Council of Agriculture, Chiayi 60044, Taiwan. ${ }^{5}$ Novel Gene Resources Laboratory, Strategic Innovation Platform, International Rice Research Institute, DAPO Box 7777, Metro Manila, Los Baños, Philippines. ${ }^{6}$ School of Biotechnology, Kalinga Institute of Industrial Technology, Bhubaneswar, Odisha 751024, India.

Received: 7 April 2021 Accepted: 26 June 2021

Published online: 02 August 2021

\section{References}

Allen MR, Frame DJ, Huntingford C, Jones CD, Lowe JA, Meinshausen M, Meinshausen N (2009) Warming caused by cumulative carbon emissions towards the trillionth tonne. Nature 458(7242):1163-1166. https://doi.org/10.1 038/nature08019

Auclair JL, Baldos E, Heinrichs EA (1982) Biochemical evidence for the feeding sites of the leafhopper Nephotettix virescens within susceptible and resistant rice plants. Int J of Trop Insect Sci 3(01):29-34. https://doi.org/10.1017/S1742 758400001855

Cheng C, Chang W (1979) Studies on varietal resistance to the brown planthopper in Taiwan. In: Brown planthopper: threat to rice production in Asia, pp 251-271

Deutsch CA, Tewksbury JJ, Tigchelaar M, Battisti DS, Merrill SC, Huey RB, Naylor RL (2018) Increase in crop losses to insect pests in a warming climate. Science 361(6405):916-919. https://doi.org/10.1126/science.aat3466

Du B, Chen R, Guo J, He G (2020) Current understanding of the genomic genetic, and molecular control of insect resistance in rice. Mol Breed 40(2):24. https://doi.org/10.1007/s11032-020-1103-3

Du B, Zhang W, Liu B, Hu J, Wei Z, Shi Z, He R, Zhu L, Chen R, Han B (2009) Identification and characterization of Bph14, a gene conferring resistance to brown planthopper in rice. Proc Natl Acad Sci U S A 106(52):22163-22168. https://doi.org/10.1073/pnas.0912139106

Edwards OR (2001) Interspecific and intraspecific variation in the performance of three pest aphid species on five grain legume hosts. Entomol Exp Appl 100(1):21-30. https://doi.org/10.1046/j.1570-7458.2001.00844.x

Fahim M, Larkin PJ, Haber S, Shorter S, Lonergan PF, Rosewarne GM (2012) Effectiveness of three potential sources of resistance in wheat against wheat streak mosaic virus under field conditions. Australas Plant Pathol 41(3):301309. https://doi.org/10.1007/s13313-012-0125-7

FAOSTAT (2020) Online statistical service. FAO, Rome. http://faostat.fao.org Herdt RW (1991) Research priorities for rice biotechnology. Rice Biotechnol 6:19-54

Horgan FG, Almazan M-LP VQ, Ramal AF, Bernal CC, Yasui H, Fujita D (2019) Unanticipated benefits and potential ecological costs associated with pyramiding leafhopper resistance loci in rice. Crop Prot 115:47-58. https:// doi.org/10.1016/j.cropro.2018.09.013

Horgan FG, Arida A, Ardestani G, Almazan MLP (2020) Temperature-dependent oviposition and nymph performance reveal distinct thermal niches of coexisting planthoppers with similar thresholds for development. PLoS One 15(6):e0235506. https://doi.org/10.1371/journal.pone.0235506

Horgan FG, Arida A, Ardestani G, Almazan MLP (2021a) Elevated temperatures diminish the effects of a highly resistant rice variety on the brown planthopper. Sci Rep 11:1-13

Horgan FG, Arida A, Ardestani G, Almazan MLP (2021b) Positive and negative interspecific interactions between coexisting rice planthoppers neutralise the effects of elevated temperatures. Funct Ecol 35(1):181-192. https://doi.org/1 $0.1111 / 1365-2435.13683$

Huang S, Cheng C, Chen C (2009) Wu W the trend of occurrence and prospective control measures of rice insect pests in Taiwan. In: Symposium on Achievements and Perspectives of Rice Protection in Taiwan, In, pp 131-147 
IRRI (2013) Standard evaluation system for rice. International Rice Research Institute, Manila

Ishii T, Brar DS, Multani DS, Khush GS (1994) Molecular tagging of genes for brown planthopper resistance and earliness introgressed from Oryza australiensis into cultivated rice, O sativa. Genome 37(2):217-221. https://doi. org/10.1139/g94-030

Jairin J, Phengrat K, Teangdeerith S, Vanavichit A, Toojinda T (2006) Mapping of a broad-spectrum brown planthopper resistance gene, Bph3, on rice chromosome 6. Mol Breed 19(1):35-44. https://doi.org/10.1007/s11032-0069040-3

Jairin J, Sansen K, Wongboon W, Kothcharerk J (2010) Detection of a brown planthopper resistance gene bph4 at the same chromosomal position of Bph3 using two different genetic backgrounds of rice. Breed Sci 60(1):71-75. https://doi.org/10.1270/jsbbs.60.71

Jena KK, Hechanova SL, Verdeprado H, Prahalada GD, Kim S-R (2017) Development of 25 near-isogenic lines (NILs) with ten BPH resistance genes in rice (Oryza sativa L.): production, resistance spectrum, and molecular analysis. Theor Appl Genet 130(11):2345-2360. https://doi.org/10.1007/ s00122-017-2963-8

Jena KK, Jeung JU, Lee JH, Choi HC, Brar DS (2006) High-resolution mapping of a new brown planthopper $(\mathrm{BPH})$ resistance gene, Bph18 (t), and markerassisted selection for $\mathrm{BPH}$ resistance in rice (Oryza sativa L.). Theor Appl Genet 112(2):288-297. https://doi.org/10.1007/s00122-005-0127-8

Jena KK, Kim S-R (2020) Genomics, biotechnology and plant breeding for the improvement of rice production. In: Accelerated Plant Breeding, vol 1. Springer, Cham. pp 217-232

Ji H, Kim S-R, Kim Y-H, Suh J-P, Park H-M, Sreenivasulu N, Misra G, Kim S-M, Hechanova SL, Kim H, Lee G-S, Yoon U-H, Kim T-H, Lim H, Suh S-C, Yang J, An G, Jena KK (2016) Map-based cloning and characterization of the BPH18 gene from wild rice conferring resistance to brown planthopper (BPH) insect pest. Sci Rep 6(1):34376. https://doi.org/10.1038/srep34376

Jiang H, Hu J, Li Z, Liu J, Gao G, Zhang Q, Xiao J, He Y (2018) Evaluation and breeding application of six brown planthopper resistance genes in rice maintainer line Jin 23B. Rice 11(1):22. https://doi.org/10.1186/s12284-018-0215-4

Kimmins FM (1989) Electrical penetration graphs from Nilaparvata lugens on resistant and susceptible rice varieties. Entomol Exp Appl 50(1):69-79. https:// doi.org/10.1111/j.1570-7458.1989.tb02317.x

Klingler J, Creasy R, Gao L, Nair RM, Calix AS, Jacob HS, Edwards OR, Singh KB (2005) Aphid resistance in Medicago truncatula involves antixenosis and phloem-specific, inducible antibiosis, and maps to a single locus flanked by NBS-LRR resistance gene analogs. Plant Physiol 137(4):1445-1455. https://doi. org/10.1104/pp.104.051243

Lamichhane JR, Dachbrodt-Saaydeh S, Kudsk P, Messéan A (2016) Toward a reduced reliance on conventional pesticides in European agriculture. Plant Dis 100(1):10-24. https://doi.org/10.1094/PDIS-05-15-0574-FE

Liu Y, Wu H, Chen H, Liu Y, He J, Kang H, Sun Z, Pan G, Wang Q, Hu J, Hu J, Zhou F, Zhou K, Zheng X, Ren Y, Chen L, Wang Y, Zhao Z, Lin Q, Wu F, Zhang X, Guo X, Cheng X, Jiang L, Wu C, Wang H, Wan J (2015) A gene cluster encoding lectin receptor kinases confers broad-spectrum and durable insect resistance in rice. Nat Biotechnol 33(3):301-305. https://doi.org/10.1038/nbt.3 069

Murata K, Fujiwara M, Kaneda C, Takumi S, Mori N, Nakamura C (1998) RFLP mapping of a brown planthopper (Nilaparvata lugens Stål) resistance gene bph2 of indica rice introgressed into a japonica breeding line 'Norin-PL4'. Genes Genet Syst 73(6):359-364. https://doi.org/10.1266/ggs.73.359

Murata K, Fujiwara M, Murai H, Takumi S, Mori N, Nakamura C (2001) Mapping of a brown planthopper (Nilaparvata lugens Stål) resistance gene Bph9 on the long arm of rice chromosome 12. Cereal Res Commun 29(3-4):245-250. https://doi.org/10.1007/BF03543667

Myint KKM, Fujita D, Matsumura M, Sonoda T, Yoshimura A, Yasui H (2012) Mapping and pyramiding of two major genes for resistance to the brown planthopper (Nilaparvata lugens [Stål]) in the rice cultivar ADR52. Theor Appl Genet 124(3):495-504. https://doi.org/10.1007/s00122-011-1723-4

Nguyen CD, Verdeprado H, Zita D, Sanada-Morimura S, Matsumura M, Virk PS, Brar DS, Horgan FG, Yasui H, Fujita D (2019) The development and characterization of near-isogenic and pyramided lines carrying resistance genes to brown planthopper with the genetic background of japonica rice (Oryza sativa L.). Plants 8:498

Oerke E-C (2006) Crop losses to pests. J Agric Sci 144(1):31-43. https://doi.org/1 $0.1017 /$ S0021859605005708
Pathak P, Heinrichs E (1982) Bromocresol green indicator for measuring feeding activity of Nilaparvata lugens on rice varieties. Philipp Entomol 5:197-198

Qiu Y, Guo J, Jing S, Zhu L, He G (2012) Development and characterization of japonica rice lines carrying the brown planthopper-resistance genes BPH12 and BPH6. Theo Appl Genet 124(3):485-494. https://doi.org/10.1007/s00122011-1722-5

Rahman ML, Jiang W, Chu SH, Qiao Y, Ham T-H, Woo M-O, Lee J, Khanam MS, Chin J-H, Jeung J-U, Brar DS, Jena KK, Koh H-J (2009) High-resolution mapping of two rice brown planthopper resistance genes, Bph2O(t) and Bph21(t), originating from Oryza minuta. Theo Appl Genet 119(7):1237-1246. https://doi.org/10.1007/s00122-009-1125-z

Rasband WS (1997) ImageJ. National Institutes of Health, Bethesda

Ren J, Gao F, Wu X, Lu X, Zeng L, Lv J, Su X, Luo H, Ren G (2016) Bph32, a novel gene encoding an unknown SCR domain-containing protein, confers resistance against the brown planthopper in rice. Sci Rep 6(1):37645. https:// doi.org/10.1038/srep37645

Sidhu GS, Khush GS (1979) Linkage relationships of some genes for disease and insect resistance and semidwarf stature in rice. Euphytica 28(2):233-237. https://doi.org/10.1007/BF00056580

Smith CM (2005) Plant resistance to arthropods: molecular and conventional approaches. Springer Science \& Business Media, Dordrecht. https://doi.org/1 $0.1007 / 1-4020-3702-3$

Stocker TF, Qin D, Plattner G-K, Tignor M, Allen SK, Boschung J, Nauels A, Xia Y, Bex V, Midgley PM (2013) Climate change 2013: the physical science basis, Contribution of working group I to the fifth assessment report of the intergovernmental panel on climate change, vol 1535

Stout M, Davis J (2009) Keys to the increased use of host plant resistance in integrated Pest management. In: Integrated Pest Management: innovationdevelopment process. Springer, Dordrecht. pp 163-181

Su C-C, Zhai H-Q, Wang C-M, Sun L-H, Wan J-M (2006) SSR mapping of brown planthopper resistance gene Bph9 in Kaharamana, an indica rice (Oryza sativa L.). Chin J Genet 33:262-268

Sun L, Su C, Wang C, Zhai H, Wan J (2005) Mapping of a major resistance gene to the brown planthopper in the rice cultivar Rathu Heenati. Breed Sci 55(4): 391-396. https://doi.org/10.1270/jsbbs.55.391

Tamura Y, Hattori M, Yoshioka H, Yoshioka M, Takahashi A, Wu J, Sentoku N, Yasui $H$ (2014) Map-based cloning and characterization of a brown planthopper resistance gene $B P H 26$ from Oryza sativa L. ssp. indica cultivar ADR52. Sci Rep 4:5872

R Core Team (2013) R: a language and environment for statistical computing. R Foundation for Statistical Computing, Vienna

Wang B-J, Xu H-X, Zheng X-S, Fu Q, Lu Z-X (2010) High temperature modifies resistance performances of rice varieties to brown planthopper, Nilaparvata lugens (Stål). Rice Sci 17(4):334-338. https://doi.org/10.1016/S1672-63 08(09)60036-6

Wang Y, Cao L, Zhang Y, Cao C, Liu F, Huang F, Qiu Y, Li R, Lou X (2015) Mapbased cloning and characterization of BPH29, a B3 domain-containing recessive gene conferring brown planthopper resistance in rice. J Exp Bot 66(19):6035-6045. https://doi.org/10.1093/jxb/erv318

Yara A, Phi CN, Matsumura M, Yoshimura A, Yasui H (2010) Development of nearisogenic lines for $B P H 25(t)$ and $B P H 26(t)$, which confer resistance to the brown planthopper, Nilaparvata lugens (Stål.) in indica rice 'ADR52'. Breed Sci 60(5):639-647. https://doi.org/10.1270/jsbbs.60.639

Zhao C, Liu B, Piao S, Wang X, Lobell DB, Huang Y, Huang M, Yao Y, Bassu S, Ciais P, Durand J-L, Elliott J, Ewert F, Janssens IA, Li T, Lin E, Liu Q, Martre P, Müller C, Peng S, Peñuelas J, Ruane AC, Wallach D, Wang T, Wu D, Liu Z, Zhu Y, Zhu $Z$, Asseng S (2017) Temperature increase reduces global yields of major crops in four independent estimates. Proc Natl Acad Sci U S A 114(35):93269331. https://doi.org/10.1073/pnas.1701762114

Zhao Y, Huang J, Wang Z, Jing S, Wang Y, Ouyang Y, Cai B, Xin XF, Liu X, Zhang C, Pan Y, Ma R, Li Q, Jiang W, Zeng Y, Shangguan X, Wang H, BoDu ZL, Xu X, Feng Y-Q, He SY, Chen R, Zhang Q, He G (2016) Allelic diversity in an NLR gene $B P H 9$ enables rice to combat planthopper variation. Proc Natl Acad Sci U S A 113(45):12850-12855. https://doi.org/10.1073/pnas.1614862113

\section{Publisher's Note}

Springer Nature remains neutral with regard to jurisdictional claims in published maps and institutional affiliations. 